\title{
Infestation of Middle Devonian (Givetian) camerate crinoids by platyceratid gastropods and its implications for the nature of their biotic interaction
}

\author{
FOREST J. GAHN AND TOMASZ K. BAUMILLER
}

LETHAIA

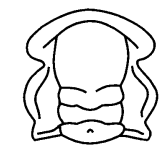

\begin{abstract}
Gahn, F.J. \& Baumiller, T.K. 200306 12: Infestation of Middle Devonian (Givetian) camerate crinoids by platyceratid gastropods and its implications for the nature of their biotic interaction. Lethaia, Vol. 36, pp. 71-82. Oslo. ISSN 0024-1164.

One of the classic examples of biotic interactions preserved in the fossil record is that between crinoids and infesting platyceratid gastropods. This relationship, spanning an interval from the Middle Ordovician to the end of the Permian, is recognized by the firm attachment and positioning of platyceratids over the anal vent of their hosts. Several hypotheses have been proposed to explain this interaction; the most widely accepted is that the gastropods were coprophagous commensals, feeding on crinoid excrement without any significant detriment to their hosts. The purpose of this investigation was to test this hypothesis. Two species of Middle Devonian camerate (Monobathrida, Compsocrinina) crinoids, Gennaeocrinus variabilis Kesling \& Smith 1962 and Corocrinus calypso (Hall 1862), were used in this investigation. The data consisted of 426 individuals of $G$. variabilis collected near Rockport, Michigan, 30 of which were infested, and 188 individuals of C. calypso collected near Arkona, Ontario, Canada, of which 25 were infested. Length and volume were measured for each crinoid to determine whether a significant difference existed in the size of infested versus uninfested individuals. The results indicated that for both species of crinoids individuals infested by snails were significantly smaller than uninfested individuals $(p<0.05)$. We explored a variety of scenarios to explain this pattern and conclude that they falsify the null hypothesis that the crinoid-gastropod relationship was strictly commensal. The smaller size of the infested crinoids is interpreted as a consequence of nutrient-stealing by the parasitic gastropods, a strategy that finds analogs in modern seas. Moreover, the absence of platyceratids on the largest crinoids suggests that large size may have inferred immunity from lasting infestation. $\square$ Crinoids, Devonian, escalation, parasitism, platyceratids.
\end{abstract}

Forest Gahn [fgahn@umich.edu] and Tomasz K. Baumiller [tomaszb@umich.edu], Museum of Paleontology, University of Michigan, Ann Arbor, MI 48109-1079, USA (current addresses: F. J. Gahn [gahnf@byui.edu], Brigham Young University, Idaho, Department of Geology, Rexburg, ID 83460-0510, USA; Tomasz K. Baumiller, Institute of Paleobiology, Polish Academy of Sciences (PAN), Twarda 51/55, PL-00-818 Warsaw, Poland; 10th September 2002, revised 4th February 2003.
Biotic interactions have been hypothesized as a major evolutionary force in fossil and recent ecosystems. To test such hypotheses necessitates correctly identifying the nature of the biotic interaction in question. One of the best-known, long-ranging, and most widely discussed interactions in marine fossil invertebrates is that between crinoids and platyceratid gastropods. This relationship was noted as early as 1843 by Austin \& Austin who, recognizing the placement of the gastropod in the arms of the crinoid, interpreted the gastropod as the crinoid's prey. This view was sustained by the Austins' contemporaries, including Yandell \& Shumard (1847), Yandell (1855), and Owen (1862), but subsequently rejected by Meek \& Worthen $(1866,1868,1873)$, who provided evidence that the crinoids and gastropods were engaged in a more semipermanent relationship. This evidence includes: (1) the tight fit between the gastropod aperture and the crinoid calyx, (2) modification of the gastropod aperture to conform to the morphology and ornamentation of the crinoid calyx (Meek \& Worthen $1866,1868)$, (3) the consistent placement of the gastropod over the anal opening of the crinoid (Meek \& Worthen 1873; Hinde 1885), and (4) permanent growth scars on the crinoid tegmen (Keyes $1888 \mathrm{a}, \mathrm{b})$. These observations led Hinde (1885) and later Keyes $(1888 \mathrm{a}, \mathrm{b}, 1890)$ to conjecture that the gastropods were feeding on crinoid excrement, a relationship known as 'coprophagy'.

Coprophagy was widely accepted throughout the twentieth century (e.g. Clarke 1908; Bowsher 1955; Lane 1978; Kluessendorf 1983; Meyer \& Ausich 1983; 
Boucot 1990), as was the interpretation that the gastropods were commensals, having no positive or negative effect on the crinoid (Keyes 1888a; Bowsher 1955; Lane 1973; Meyer \& Ausich 1983). However, other ideas as to the nature of the relationship and its effect on crinoids have been offered. For example, Lane (1973) and later, Wood (1980, p. 110) considered that the crinoid might have benefited from a coprophagous gastropod that served as a 'competent elimination system', clearly arguing that this represented a case of mutualism. More common have been suggestions that the presence of the gastropods was detrimental, although not fatal, to the crinoid. Such a parasitic relationship was favored by Clarke (1921, p. 64) who stated '... [The] gastropod ... must have been obnoxious to it [the crinoid] as it interfered with the normal alimentary function'. Thomas (1924, p. 451) concurred, arguing that crinoids 'were unquestionably the unhappy hosts of a weighty and persistent parasite'. Nevertheless, Clarke (1921) and Thomas (1924) also supported a coprophagous behavior among the gastropods.

The strictly coprophagous nature of the gastropodcrinoid interaction was less widely accepted in the nineteenth century than it was in the twentieth. For example, Meek \& Worthen (1873) postulated that the gastropods were feeding on microorganisms brought in via currents produced by crinoid arms or trapped in the ambulacral (food) grooves. Even Keyes (1888a, p. 240), who strongly supported a coprophagous habit for platyceratids, mentioned, 'nourishment from other sources may also have been obtained'. More recently, Lane (1984) suggested that gastropods fed on crinoid gametes (gametophagy) shed through the anal vent. This idea was supported by the fact that whereas the gametes of modern crinoids are located on their proximal arms in specialized genital pinnules, such pinnules have not been recognized on the arms of Paleozoic crinoids. Lane argued that those crinoids must have shed their gametes through the anal vent, which was occupied by the gastropod.

Baumiller (1990, 2001) also suggested that gastropods positioned over the crinoid anal opening could have fed on more than just crinoid rejectamenta; for example, they may have stolen undigested nutrients from their host and thus have been kleptoparasitic. He supported kleptoparasitism by noting that among extant comatulid crinoids, the captured and still largely undigested food travels rapidly to the hindgut where most digestion occurs (Holland et al. 1991). If this were true of Paleozoic crinoids, infesting gastropods could reach through the anal opening into the hindgut with their proboscis and extract undigested nutrients. The plausibility of the kleptoparasitic scenario was recently quantified using a cost-benefit analysis (Baumiller 2001). Because it involves the consumption of food particles from the crinoid gut, we will hence refer to this habit as 'gastrophagy'.

Although coprophagous, gametophagous and gastrophagous interpretations are plausible, we are interested in distinguishing among them through explicit testing. One such test involves comparing the sizes of infested and uninfested individuals from a single population of crinoids. All else being equal, one might expect that neither coprophagous nor gametophagous snails should influence the growth of infested crinoids. Thus, under those scenarios there should be no difference in the size distribution of infested and uninfested individuals from the same population. On the other hand, a snail that steals nutrients might stunt the host's growth rate, resulting in a pattern that may be reflected in the size distribution of infested and uninfested individuals. Rollins \& Brezinski (1988) examined size differences of infested and uninfested individuals of the camerate crinoid Platycrinites and found infested individuals to be smaller, on average, than uninfested individuals. They interpreted their results as indicating that infested crinoids were subject to either diminished growth rates or premature death. However, they did not invoke nutrient-stealing as a mechanism for the observed pattern, but instead suggested that the gastropods adversely affected crinoid balance and feeding orientation. The small sample size (infested $n=11$ and 1 , uninfested $n=6$ and 3) used in their study, and the fact that the comparison involved infested individuals from one set of crinoid 'stands' and uninfested individuals from another set of 'stands' allowed neither establishment of statistical significance nor ceteris paribus. Nevertheless, the study of Rollins \& Brezinski (1988) provides one explicit test for evaluating the nature of the platyceratid-crinoid relationship and one that was followed in this study, albeit with some modifications.

\section{Geologic setting and taphonomy}

Two large collections of the camerate (Monobathrida, Compsocrinina) crinoid species Gennaeocrinus variabilis Kesling \& Smith 1962 and Corocrinus calypso (Hall 1862) were the focus of this study. Both species are from the Middle Devonian (Early Givetian) Hamilton or Traverse Group of North America. The population of $G$. variabilis was collected from the Bell Shale near Rockport, Alpena County, Michigan and specimens of $C$. calypso were sampled from the Arkona Shale near Arkona, Lambton County, Ontario, Canada (Fig. 1). The Bell Shale is exposed only on the northeastern edge of the Michigan Basin, but it is present in the subsurface throughout eastern Michi- 
gan and southwestern Ontario (Rickard 1984). The Arkona Shale is located on the southeastern margin of the Michigan Basin and correlates with the better known Silica Shale of Michigan and Ohio (Brett 1999). Only $10 \mathrm{~m}$ of the Arkona Shale are naturally exposed in Ontario; however, well logs indicate that an additional $10 \mathrm{~m}$ are buried in the subsurface (Rickard 1984). Furthermore, the Arkona Shale directly overlies the Rockport Quarry Limestone, which is the forma- tion that immediately overlies the Bell Shale of Michigan.

The Bell Shale consists of blue-gray mudstone that is unfossiliferous for the most part, but contains thin horizons of abundant, diverse and well-articulated marine invertebrates. These stringers usually consist of a thin $(1-2 \mathrm{~cm})$ skeletal packstone or grainstone comprised mostly of disarticulated to partially articulated crinoid material. Such horizons are overlain by
Rockport, MI

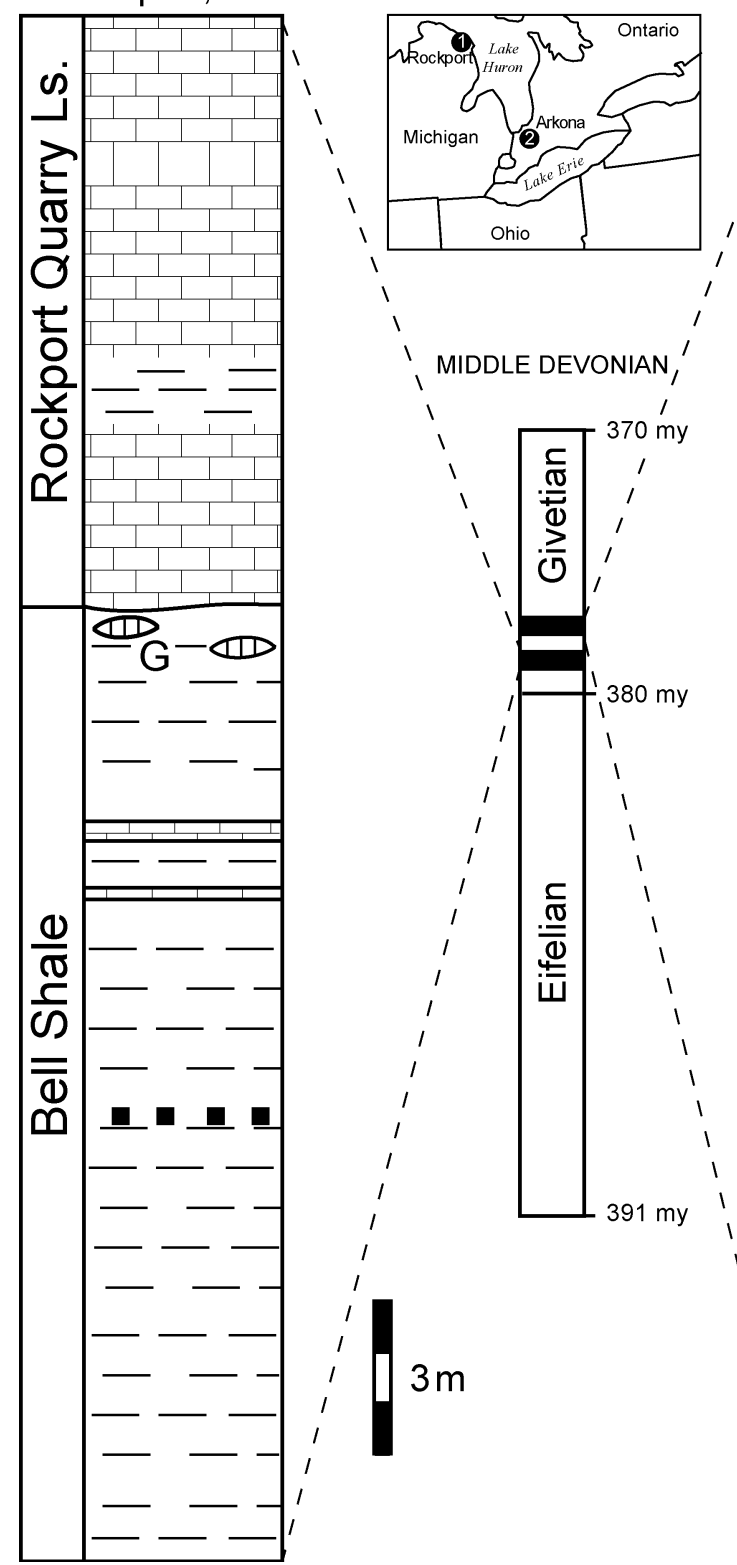

Arkona, Ontario

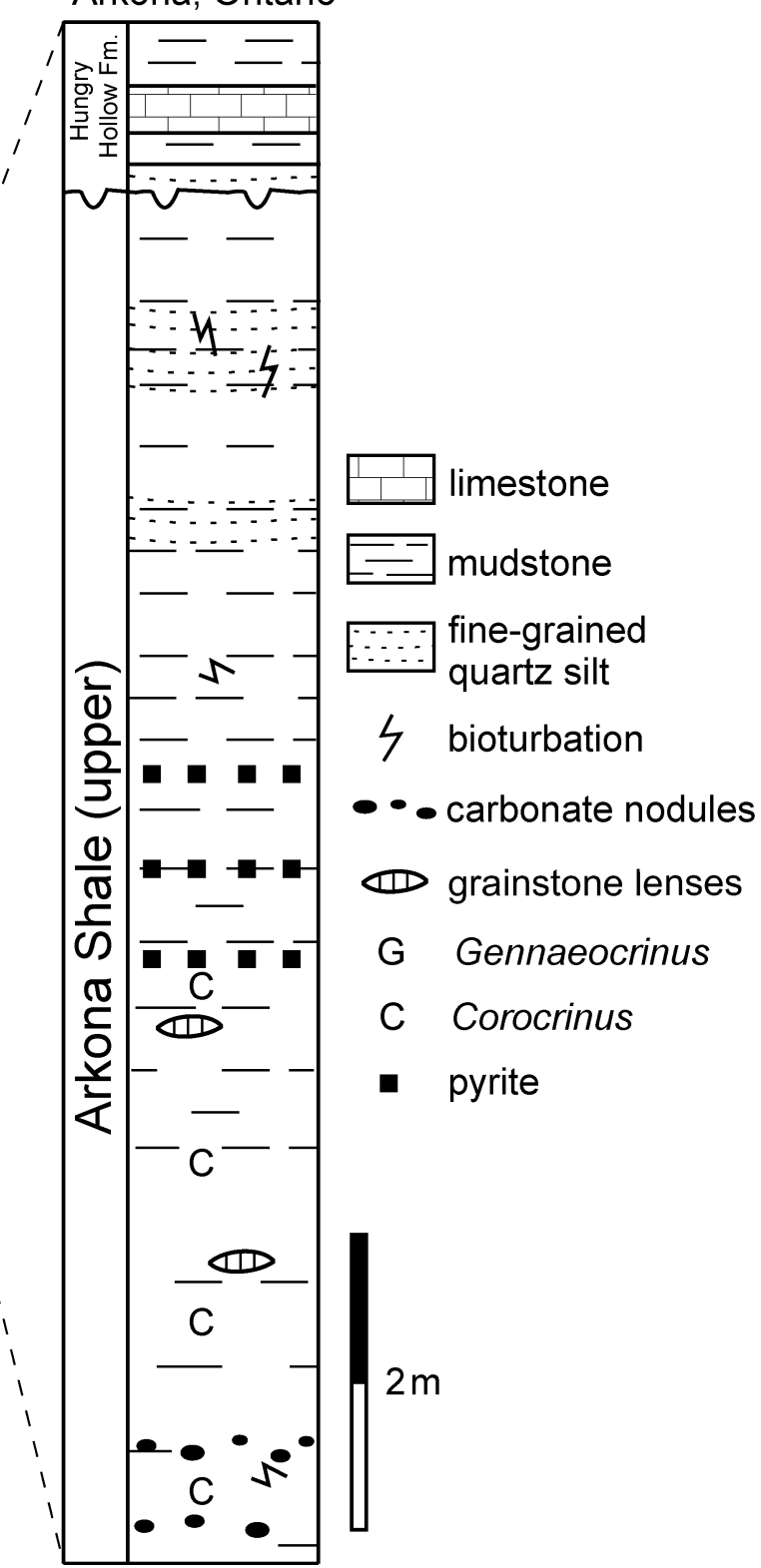

Fig. 1. Locality map and generalized stratigraphic sections of field localities. The locality map (top center) indicates the relative position of the stratigraphic sections in this study. The vertical bar (center) represents the relative stratigraphic positions of the two sections in the Middle Devonian (Givetian). Specimens of Gennaeocrinus variabilis Kesling \& Smith 1962 used in this study were collected from the Bell Shale of Rockport, Michigan (left column) and the horizon of their occurrence is indicated (G). Specimens of Corocrinus calypso (Hall 1862) used in this study were collected from the Arkona Shale of Arkona, Ontario (right column) and the range of their occurrence is indicated (C). 
$1-2 \mathrm{~cm}$ of mudstone that contains a well-articulated fauna, including articulated brachiopods, and complete crinoid and blastoid crowns with partial stalks.

The specimens of Gennaeocrinus variabilis used in this study were collected along a low bench west of the old quarry buildings associated with the abandoned Kelley's Island Lime and Transport Company (Fig. 2). The exposure is limited, measuring approximately $30 \mathrm{~m}$ in length, but has yielded several hundred calyxes of G. variabilis during the past 50 years (Kesling \& Smith 1962). Most of the specimens of $G$. variabilis were collected as loose calyxes weathered out of the exposure; however, excavation of the locality has uncovered only a single Gennaeocrinus-bearing layer (R.S. Vergiels 2002, pers. comm.). This horizon has produced large numbers of $G$. variabilis with wellpreserved crowns suggesting rapid burial of a single population. The arms on these specimens are extremely fragile and are easily disassociated as they weather from the soft mudstone. Therefore, it is not surprising that the arms of most of the surface collected specimens were not recovered and that most specimens are represented by single, loose calyxes. All of the Gennaeocrinus individuals used in this study were either directly excavated or weathered from a single horizon. We interpret this horizon as a storm bed, preserving a coeval assemblage of $G$. variabilis.

Individuals of Corocrinus calypso from the Arkona Shale were collected from bluish-gray mudstones overlying thin, crinoid-rich packstone to grainstone lenses from the old clay pits along the Ausable River (Fig 3). Individuals of C. calypso have been collected from several horizons ranging from below to several meters above the river level, the upper range boundary being delineated by an interval containing abundant pyrite (M. Topor 2002, pers. comm.). This species occurs in several discrete horizons characterized by crinoid packstone and grainstone lenses, although most of the specimens are collected in the mudstone that directly overlies these lenses. Furthermore, $C$. calypso frequently occurs with Arthroacantha carpenteri (Hinde 1885), the most abundant and well-known crinoid from the Arkona and Silica Formations and a species that is also heavily infested by Platyceras. Although most of the crinoid beds in the Arkona Shale contain specimens with well-preserved arms and stalks, the soft and easily weathered nature of the mudstone makes it difficult to extract complete specimens, resulting in the majority of individuals being represented by loose calyxes. Furthermore, unlike the occurrence of Gennaeocrinus variabilis from the Bell Shale, it is impossible to assign the $C$. calypso specimens to a single bed. Therefore, we cannot exclude the possibility that these represent members of temporally isolated populations.

The Bell and Arkona Shales were deposited in moderately deep, middle shelf marine environments below average storm wave base (Ehlers \& Kesling 1970; Brett 1999). The soft, muddy substrate supported an invertebrate community consisting primarily of brachiopods, bryozoans, echinoderms and mollusks. The paucity of body fossils in the majority of the mudstones of the Bell and Arkona Shales suggests deposition in marginally aerobic to occasionally dysaerobic environments (Landing \& Brett 1987). The thin brachiopod and crinoid-dominated packstone to grainstone lenses are interpreted as localized living sites. The sediments of these living sites were winnowed through storm-generated currents and sediment flows that entombed intact marine invertebrates. The echinoderms in these units show morphologic adaptations consistent with life on soft, muddy substrates, including radicular stalks and holdfasts (Arthroacantha), and anchor-like (Ancyrocrinus) and prehensile (Gilbertsocrinus) holdfasts. The soft bottom dwelling stalked echinoderms may have provided a substrate for subsequent inhabitants either through the process of positive taphonomic feedback, wherein their death and disarticulation provided localized skeletal substrates on which other organisms could survive (Kidwell \& Jablonski 1983; Brett 1999), or more directly, as hosts of organisms such as platyceratid gastropods.

\section{Crinoid and gastropod taxonomy}

The genera Gennaeocrinus and Corocrinus are moderately common Devonian camerate crinoids that first appear during the Early Devonian (Emsian) of Spain and Germany, and range into the Middle to Late Devonian (Givetian to Frasnian) of North America. Gennaeocrinus is currently represented by approximately 30 species and Corocrinus by six (Webster 1999). However, the systematic placement of species assigned to both genera is in need of taxonomic revision, as several of the species in these genera may belong to as-of-yet undescribed genera (G.M. McIntosh 2002, pers. comm.). We are unaware of previously published reports of either of these two genera being infested with platyceratid gastropods, and this may represent the first such account. It is worth noting that these genera are thought to share common ancestry with members of the family Actinocrinitidae (Wachsmuth \& Springer 1881; Moore \& Laudon 1943; Ubaghs 1978), which consists of genera that radiated explosively in the Early 

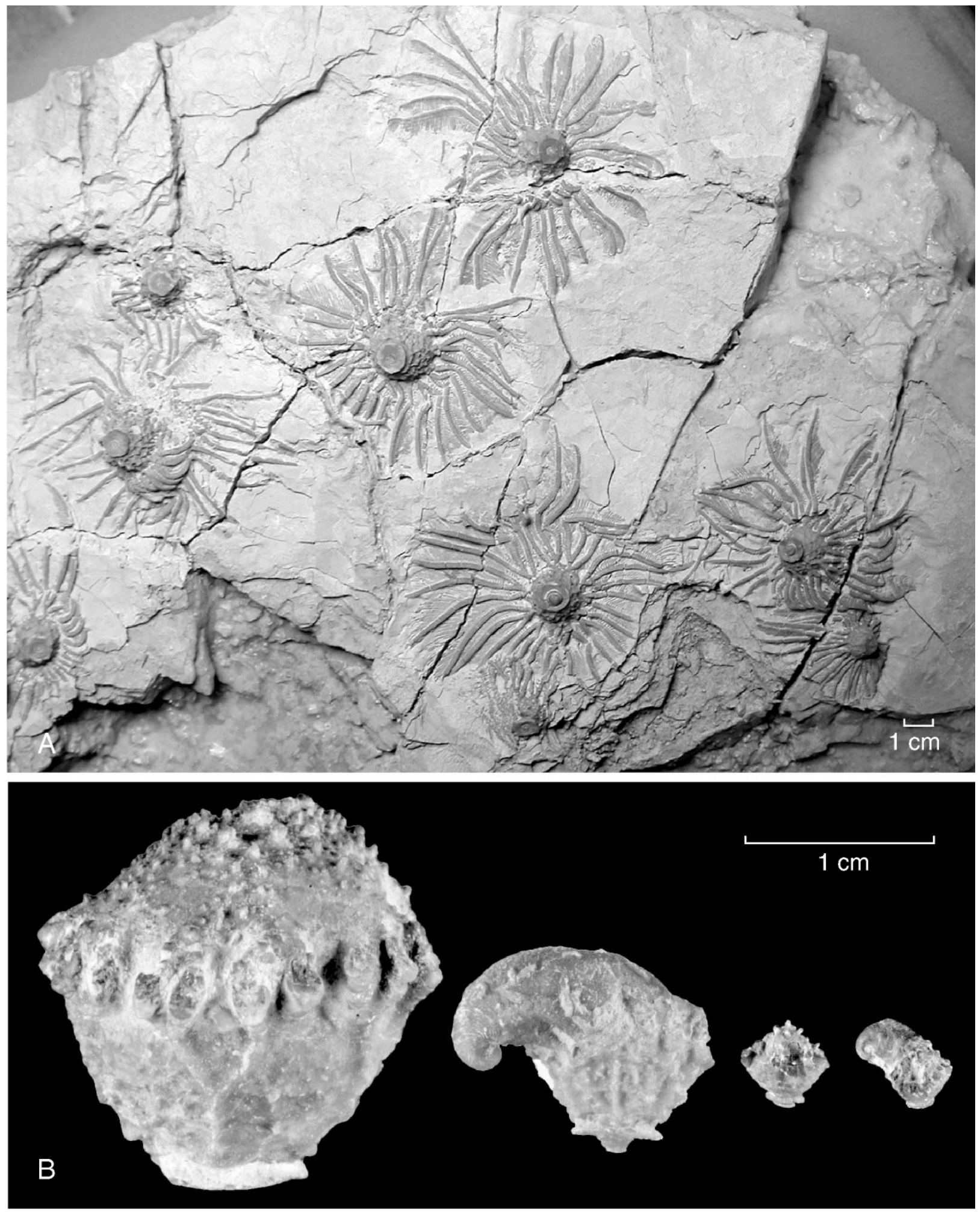

Fig. 2. Representatives of Gennaeocrinus variabilis Kesling \& Smith 1962. $\square$ A. Large mudstone slab bearing G. variabilis from the Bell Shale of Rockport, Michigan, preserving several crowns in a starburst orientation (from the private collection of J. \& M. Topor). $\square$ B. Largest (left) and smallest (right) pairs of infested and uninfested specimens of G. variabilis. 

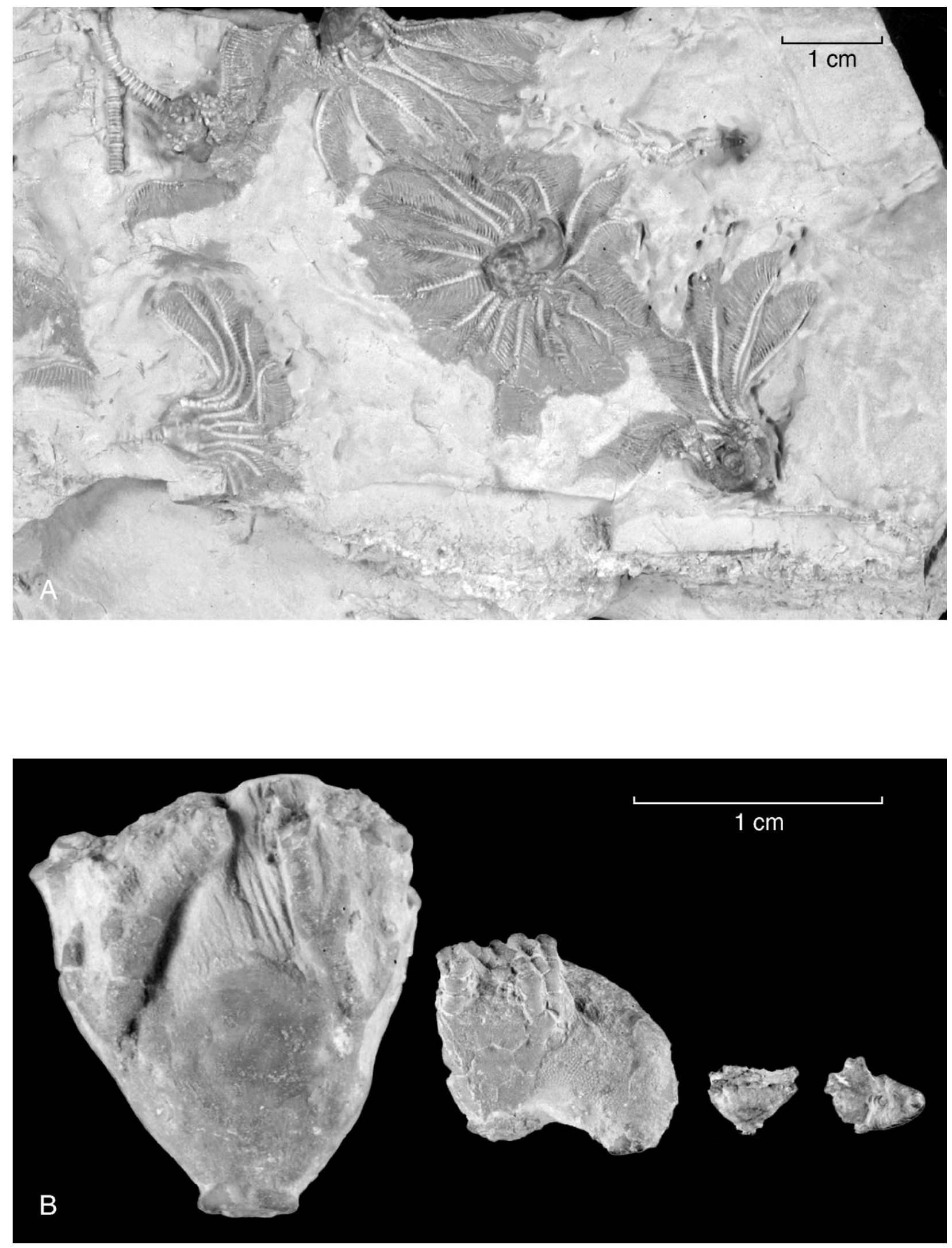

Fig. 3. Representatives of Corocrinus calypso (Hall 1862). $\square$ A. Mudstone slab bearing C. calypso from the Arkona Shale of Arkona, Ontario, Canada, preserving several infested and uninfested crowns (from the private collection of J. Koniecki). $\square$ B. Largest (left) and smallest (right) pairs of infested and uninfested specimens of C. calypso. 
Mississippian and commonly served as hosts to platyceratids.

The Platyceras species found associated with Gennaeocrinus variabilis and Corocrinus calypso are morphologically similar; both are relatively small representatives of the genus with a widely expanded body whorl and a diminutive apex. Both species of Platyceras also lack spines, a character that is commonly found on Platyceras rarispinum Hall 1879, a platyceratid frequently associated with Arthroacantha carpenteri from the Arkona and Silica Shales. The most obvious difference between the platyceratids infesting G. variabilis and C. calypso is the nature of the coiling at the apex of the shell; the species associated with the former has a nearly complete coil developed, whereas the species associated with the latter has approximately half a coil. However, distinguishing among the species of platyceratids is notoriously difficult, because they were able to adjust their aperture shape and shell morphology to the surface contours of their host (Bowsher 1956; Knight et al. 1960). Several nonspinose platyceratid species have been described from the Arkona Shale (Stumm \& Wright 1958), including Platyceras bucculentum Hall 1879, Platyceras erectum (Hall 1879), and Platyceras thetis Hall 1879; however, extensive species lists compiled on the Bell Shale make no mention of platyceratids (Stumm 1951, 1961; Ehlers \& Kesling 1970). We do not feel comfortable assigning any of the gastropods associated with the crinoids in this study to known species. We hesitate to make more explicit species assignments because the morphology of the platyceratids found with $G$. variabilis and $C$. calypso is not consistent with described species. This may be, in part, due to the size of these gastropods; the platyceratids infesting $G$. variabilis and $C$. calypso are very small, whereas the described species from the Arkona and Silica Shales are based on much larger specimens.

It is possible that the platyceratids found infesting Gennaeocrinus variabilis and Corocrinus calypso represent undescribed species. The platyceratids associated with these crinoids only occur in concentrations of their respective hosts (M. Topor \& R.S. Vergeils 2002, pers. comm.). The restricted occurrence of these species of Platyceras with crinoids may, in part, explain why the Bell Shale species lists do not include platyceratids (Stumm 1951, 1961; Ehlers \& Kesling 1970); these platyceratids may have simply gone unrecognized in the absence of large collections of their respective hosts.

\section{Materials and methods}

The data for this study consist of 614 individual crinoids, represented by 426 specimens of Gennaeocrinus variabilis and 188 specimens of Corocrinus calypso. Thirty of the $426(7 \%)$ individuals of $G$. variabilis and 25 of the $188(13 \%)$ individuals of $C$. calypso were infested by platyceratid gastropods. Although several complete crinoids were available for study, we used only calyxes free of matrix for ease of measurement and taphonomic constancy. Furthermore, specimens that possess well-preserved arms are typically encased in matrix, making only half of the specimens available for study and adding uncertainty to our assessment of the presence or absence of infesters.

To compare the size of uninfested to infested crinoids, we used several measures. The simplest and most easily obtained measure was the distance from the proximal edge of the basal plates to the tegmen (M1), which essentially corresponds to the height of the calyx (Fig. 4A). Because the growth of G. variabilis and C. calypso is slightly allometric (with smaller specimens having a greater width to height ratio), we also took two other measurements: the distance from the $\mathrm{C}-\mathrm{D}$ interray to the $\mathrm{A}$ ray $(\mathrm{M} 2)$, and the distance from the B-C interray to the E ray (M3) (Fig. 4B). Volume was also obtained for a subsample of specimens using the Archimedean principle; specimens representing a range of cup heights were submerged in a beaker of water and their volume was estimated by the weight of displaced water. Qualitatively, the results of the size comparisons of infested and uninfested crinoids did not vary between different linear and volumetric size metrics. Therefore, we only present the data for size based on the measurement of M1.

Linear measurements of infesting platyceratids included the maximum height of the gastropod (S1), the maximum width of the aperture (S2), and the width of the aperture perpendicular to the maximum

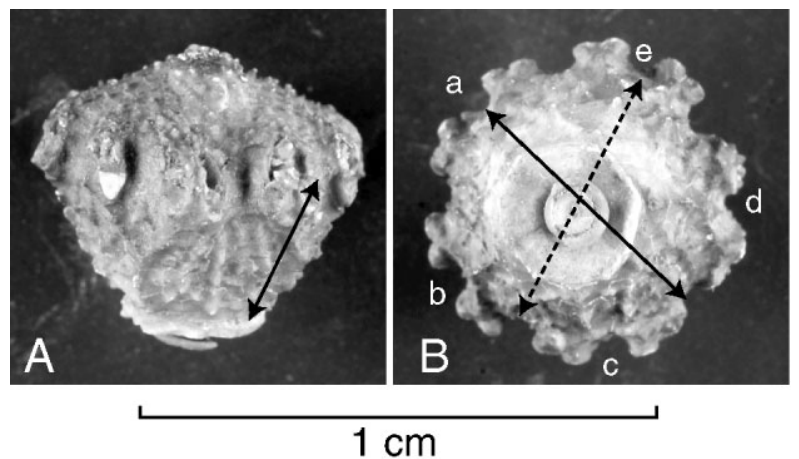

Fig. 4. Size measurements in crinoids. $\square$ A. The solid arrow represents the measurement from the top of the basal rim to the middle of the arm facet (M1). $\square \mathrm{B}$. The solid arrow represents the measurement from the A-ray to the $\mathrm{C}-\mathrm{D}$ interray (M2). The dashed arrow represents the measurement from the E-ray to the $\mathrm{B}-\mathrm{C}$ interray (M3). 
width of the aperture (S3). We did not gather volumetric data for the gastropods, as strict linear measurements sufficed for the crinoid data against which we were comparing.

\section{Results and discussion}

The most striking result of this study is the significant difference between the size of uninfested and infested crinoids. The mean size (M1) of uninfested individuals of Gennaeocrinus variabilis is $4.5 \mathrm{~mm}$, whereas for infested individuals it is $2.4 \mathrm{~mm}$ (Fig 5). This difference in means is statistically significant at $p<$ 0.001 ( $t$ test). These differences are not as pronounced in Corocrinus calypso, but uninfested crinoids remain significantly $(p<0.02)$ larger (mean $\mathrm{M} 1=5.2 \mathrm{~mm}$ ) than infested ones (mean $\mathrm{M} 1=4.2 \mathrm{~mm}$ ) (Fig. 6). Several abiotic mechanisms could explain the observed pattern of infested crinoids being significantly smaller than uninfested crinoids. We first considered potential taphonomic biases. These include a preference for the preservation of larger or smaller crinoids, or a preference for the preservation of infested versus uninfested crinoids. To test the effects of crinoid size on compaction, we recreated the frequency histograms of Gennaeocrinus and Corocrinus using only the data for uninfested and uncompressed specimens. The distribution of these histograms was not significantly different from those using all of the data, suggesting that there was no size-related taphonomic bias in crinoid preservation - not at least as far as compaction is concerned. To test the effects of the presence of gastropods on crinoid preservation, we recreated the histograms using only the uncompressed data for infested and uninfested individuals. The difference between the histogram distributions for infested and

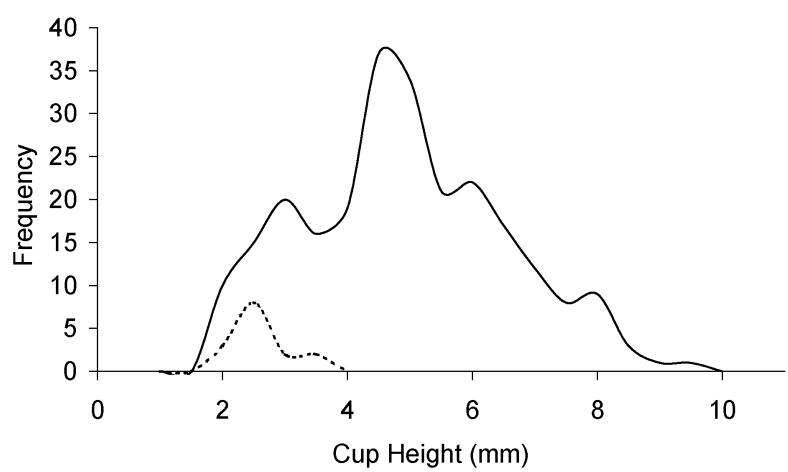

Fig. 5. Size frequency distribution of infested and uninfested individuals of Gennaeocrinus variabilis Kesling \& Smith 1962. Uninfested individuals of $G$. variabilis are represented by the solid line $(n=396$, mean M1 $=4.5 \mathrm{~mm})$. Infested individuals are represented by the dashed line $(n=30$, mean M1 $=2.4 \mathrm{~mm})$. uninfested crinoids was not significant, suggesting that the presence or absence of an infesting platyceratid had no noticeable effect on crinoid preservation. The taphonomic processes acting on large versus small and infested versus uninfested individuals are likely to have been too similar to produce the observed pattern. Moreover, we are unaware of any mechanism that would favor the preservation of large uninfested individuals preferentially to small infested individuals.

Although compaction may not have biased the sizefrequency distribution of the crinoids or the relative size-frequency distribution of infested versus uninfested specimens, compaction may have caused the frequency of infestation to be underestimated. Approximately $38 \%$ of G. variabilis specimens have slight to moderate compaction, and $78 \%$ of C. calypso specimens had slight to complete compaction. Populations of $C$. calypso were more strongly affected by processes resulting in compaction; whereas no specimens of $G$. variabilis had complete compaction, approximately $13 \%$ of $C$. calypso specimens were completely flattened. Compacted specimens may be more likely to undergo mechanical breakage during weathering or collecting processes. Most of the mudstone excavated from the vicinity of the crinoidproducing layer was collected in buckets and washed to extract any small skeletal material that might otherwise go unnoticed (J. Topor, M. Topor \& R.S. Vergiels 2002, pers. comm.). Small Gennaeocrinus and Corocrinus individuals and fragments, as well as loose platyceratids were frequently isolated from these washings. It is possible that the washing process was the cause of crinoid fragmentation and the disassociation of the platyceratids from their hosts - especially in specimens that were strongly to completely compressed. If this was the case, we might predict an increase in infestation frequency in species such as $C$. calypso, which is largely represented by strongly to

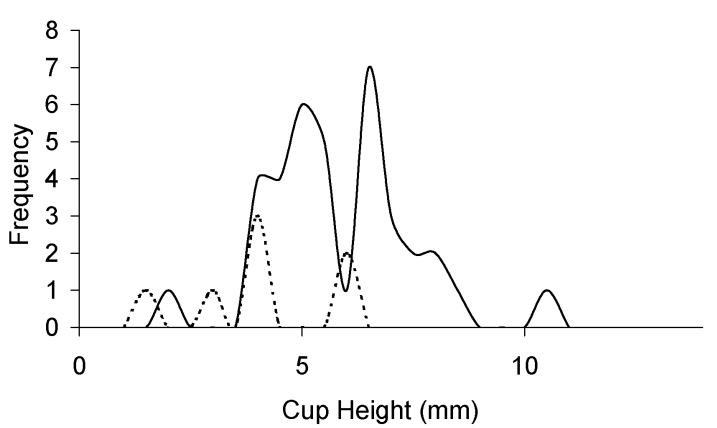

Fig. 6. Size frequency distribution of infested and uninfested individuals of Corocrinus calypso (Hall 1862). Uninfested individuals of $C$. calypso are represented by the solid line $(n=163$, mean $\mathrm{M} 1=5.2 \mathrm{~mm})$. Infested individuals are represented by the dashed line $(n=25$, mean $\mathrm{M} 1=4.2 \mathrm{~mm})$. 
completely flattened individuals, if we were to calculate infestation frequency for only uncompressed specimens. Indeed, if we estimate infestation frequency using only uncompressed specimens of $C$. calypso, this value increases from $13 \%$ to $19 \%$, whereas for the less frequently and less severely compressed $G$. variabilis, infestation frequency remains essentially the same.

Another potential source of bias is that infesting platyceratids became dislodged from their hosts through biostratinomic processes. The separation of some individuals from their hosts prior to burial is possible, and unassociated platyceratids are found in the crinoid-bearing horizons. However, as explained above, many of these specimens may have become dislodged during collection. Furthermore, it is unlikely that biostratinomic separation of the crinoid and gastropod produced the observed pattern of size differences. First, the number of isolated platyceratids is much smaller than the number of uninfested crinoids, suggesting that during life some crinoids remained uninfested. Second, if the crinoids were dislodged we would still expect to recognize platyceratid growth scars on the tegmen of the host (at least in specimens that are not strongly compacted). Third, the complete crinoids recovered from the obrution layer are large and lack platyceratids, confirming the presence of large uninfested individuals in life. Fourth, although this process is likely to have influenced the count of infested and uninfested individuals, reducing the former and inflating the latter, we cannot think of a process that would preferentially dislodge platyceratids from large crinoids. Thus, although we expect that the percentage of infested crinoids was probably larger than observed $(7-13 \%)$, the differences in size of infested and uninfested crinoids were as observed.

Another possible cause of the observed pattern could be that the infested and uninfested individuals do not represent a single population. If the infested individuals represent a population that lived under less optimal conditions (e.g. nutrient poor or dysoxic environment) than the population of uninfested individuals, their smaller size could be unrelated to the presence/absence of infesting platyceratids. However, as discussed above, only one Gennaeocrinusbearing horizon has been identified in several decades of intensive collecting. Therefore, it must be assumed that infested and uninfested individuals of this species come from the same horizon and, based on the exquisite preservation of complete crowns, that they were likely to have been buried alive by the same event. In contrast, the Corocrinus sample may well represent multiple populations, but even in this case stratigraphically separated Corocrinus-bearing horizons contained both infested and uninfested crinoids, suggesting that a much more complex scenario would be required to explain the observed pattern than a simple difference in environmental conditions.

We conclude that the observed differences in size of infested and uninfested crinoids represent a real signal rather than being an artifact of taphonomic or collecting processes. Moreover, we argue that a parasitic interpretation of the crinoid-platyceratid interaction best explains the data presented. As discussed above, neither coprophagy nor gametophagy is likely to negatively affect the size of a host crinoid. On the other hand, if the gastropods interfered with crinoid feeding efficacy or engaged in gastrophagy, the growth rate of the infested individuals may be dampened. Two additional patterns lead us to conclude that kleptoparasitism, or more specifically, gastrophagy, is the cause of smaller mean body size in infested individuals.

The first observation is that none of the largest crinoids is preserved with attached platyceratids. This suggests that large body size in G. variabilis and $C$. calypso effectuates immunity from lasting infestation. This pattern is striking because if one accepts that platyceratids are largely sessile as adults and that their motility is restricted to their time in the plankton when they find and settle on a host, the largest crinoids would appear to provide the best 'real estate' or the largest and most accessible site for settlement. They would also appear to make better hosts for gastrophages because of their ability to capture more nutrients (likewise for coprophages, because they would produce more waste). However, if these platyceratids were gastrophagous, they would have to reach into the crinoid gut to steal nutrients, and the larger the host the longer the proboscis needed to reach through the anus and into the hindgut where food is transported and digestion occurs. Under this scenario, once the crinoids reached a certain size they would be largely immune from permanent infestation because the juvenile platyceratids settling on their tegmen could not reach their gut.

Crinoid dorsal cup height and platyceratid height have a significant positive correlation (Spearman correlation $p<0.05$ for Gennaeocrinus variabilis and $p<0.001$ for Corocrinus calypso); small gastropods are associated with small crinoids and large gastropods with large crinoids. This pattern is consistent with the gastrophagy scenario; the small platyceratids on small crinoid hosts are those that recently settled, and larger platyceratids on larger hosts are those that settled on small crinoids and were living on them for an extended period, feeding on the nutrients captured by their hosts, and thus reducing the crinoid's growth rate. The reduction in growth rate of infested individuals prevented them from reaching the same size as 
those crinoids that remained uninfested. The general absence of small gastropods on large hosts implies that these crinoids had reached a size that made them immune from successful infestation. The proboscis of juvenile gastropods was likely ineffective in nutrient stealing from larger hosts and those snails that did settle on large crinoids were likely to starve.

We explored the gastrophagy scenario with a computer model (Fig. 7). The model starts with a small number of crinoid juveniles at time $t_{0}$. In each incremental time step, each crinoid could (1) grow at a rate 'a', (2) reproduce with a probability 'b', (3) die with a probability ' $c$ ', and (4) become infested by juvenile platyceratids with a probability ' $d$ '. Infestation could affect growth rate (' $\left.\mathrm{a}^{\star}\right)$, probability of death (' $c^{\star}$ ) or both. Infesting gastropods could also grow at a rate 'e'. In each time increment, each crinoid surviving from the previous time increment was subject to each of these variables, and the growth of the population was governed by a logistic equation. Crinoids that died, whether infested or not, were removed from the population, as were their infesters. The model was allowed to run for 100 time increments, although we found that in all runs the standing population stabilized after approximately 25 increments.

The goal of the model was to identify parameters that could produce a population at the end of the 100 time increments that approximated many of the characteristics of the observed population of Gennaeo-

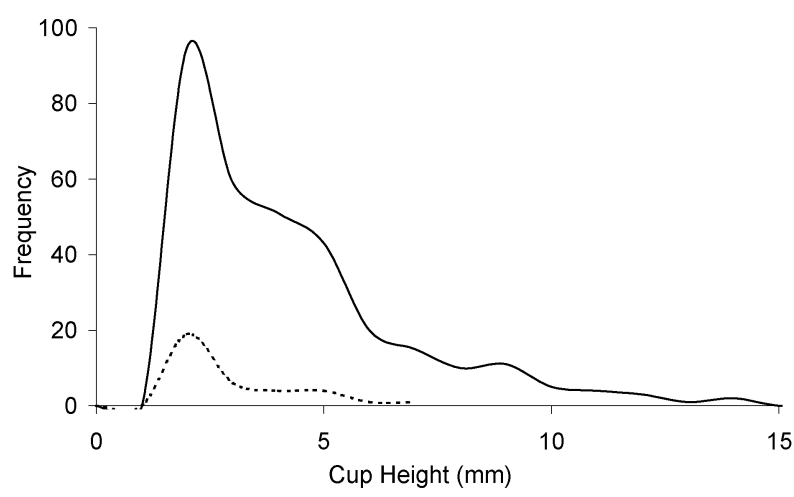

Fig. 7. Model results showing the size distribution of uninfested (solid line) and infested (dashed line) individuals in the live population after 100 time increments. The model parameters include: infestation probability $=0.045$; growth rate of infested individuals $=0.015 \mathrm{~mm}$; growth rate of uninfested individuals = $0.45 \mathrm{~mm}$ (all expressed per unit time interval). Initial size of population $=2$ individuals; birth probability $=$ death probability $=0.1$. In this model the probability of infestation is inversely proportional to the size of the crinoid. The results compare favorably to Gennaeocrinus data: mean size of uninfested individuals model = $4.5 \mathrm{~mm}$, Gennaeocrinus $=4.5 \mathrm{~mm}$; mean size of infested individuals model $=2.4 \mathrm{~mm}$, Gennaeocrinus $=2.4 \mathrm{~mm}$; number of uninfested individuals model $=372$, Gennaeocrinus $=396$; number of infested individuals model $=28 ;$ Gennaeocrinus $=30$. crinus variabilis. The characteristics we focused on included: number of infested crinoids, number of uninfested crinoids, average size of infested crinoids, and the average size of the uninfested crinoids. Parameters were adjusted by hand through 'trial and error'. The model was not an attempt to find the best solution, but rather to heuristically explore which of the biological scenarios discussed earlier could produce the observed patterns.

This model suggests that the size-frequency histograms for Gennaeocrinus variabilis are not a simple consequence of infesters reducing the growth rate or affecting the death rate of their hosts. The effect of crinoid size on infestation is also an important consideration. One obvious way of implementing this effect is to allow infestation only of those crinoids below a certain size threshold, but we found that essentially the same pattern could be produced if the probability of infestation was inversely proportional to the size of the host. Either way, it appears that by reaching a certain size, crinoids became immune from permanent infestation. The biological explanation we offer is gastrophagy - the proboscis of juvenile gastropods was not long enough to reach the gut of larger hosts.

\section{Conclusion}

The size distribution of infested and uninfested crinoids from Middle Devonian strata of Michigan and Ontario indicates that infested crinoids are smaller, on average, than the uninfested crinoids. This pattern appears not to be an artifact of taphonomic or collecting processes and requires a biological explanation. The most obvious explanation is that the presence of a gastropod on a crinoid had a negative effect on the growth rate of the host. In other words, the relationship between platyceratid and crinoid is best characterized as parasite and host, respectively. However, this effect alone is insufficient to explain the absence of small (juvenile) gastropods on large crinoids. The latter requires that the probability of infestation be inversely related to the size of the crinoid. The gastrophagy scenario proposes that gastropods supported themselves on the nutrients that are extracted from a crinoid host with their proboscis. Because the length of the proboscis is a function of the size of the gastropod and the distance to the gut is a function of the host's size, crinoids could escape permanent infestation by gastrophagous platyceratids once they achieved large size.

If, as we argue, the parasitic gastrophagy scenario characterized the relationship between platyceratids and crinoids, one might expect it to lead to evolu- 
tionary escalation (Vermeij 1987, 1994, 1999). Available data on Mississippian crinoids and the associated platyceratids suggests that escalation may indeed have occurred (Baumiller 1990; Gahn \& Baumiller 2001). Many Mississippian crinoids closely related to the Gennaeocrinus lineage evolved long anal tubes and were largely immune from infestation, whereas some of their sister taxa lacking such tubes are commonly found with attached platyceratids. One interpretation of this pattern is that the tube served as antiplatyceratid device that removed the gut even further away from the anal vent, making the gut less accessible to the proboscis of an infesting platyceratid. In a handful of instances (fewer than a dozen), platyceratids are found attached to tube-bearing camerate crinoids, but to the base of the tube, rather than its anus-bearing apex. When sectioned, a hole underneath the snail indicates that drilling of the host had occurred (Baumiller 1990). If the anal tube of these crinoids evolved as a response to parasitism, followed by a change in behavior of the infesting gastropod (drilling), this may provide a strong case for evolutionary escalation.

Acknowledgements. - This work was supported by grants from the National Science Foundation and the Petroleum Research Fund of the American Chemical Society. The investigation would not have been possible without the tireless collecting efforts, scientific responsibility, and field acumen of several members of the Friends of the University of Michigan Museum of Paleontology (FUMMP). These people include: A. Fabian, S. Hyne and R.S. Vergiels, who provided access to specimens of Gennaeocrinus variabilis, and J. Koniecki, J. Topor and M. Topor, who provided access to specimens of Corocrinus calypso from their personal collections. Moreover, we sincerely thank E. Roberts for her assistance with data gathering and citation organization, and B. Miljour for her assistance with the illustrations. The manuscript was much improved by comments and suggestions from W.A. Ausich and S.K. Donovan, who reviewed the manuscript prior to publication.

\section{References}

Austin, T., Austin, T. 1843-1846: Monograph on Recent and Fossil Crinoidea. 128 pp. Bristol and London.

Baumiller, T.K. 1990: Non-predatory drilling of Mississippian crinoids by platyceratid gastropods. Palaeontology 33, 743-748.

Baumiller, T.K. 2001: Cost-benefit analysis as a guide to the ecology of drilling platyceratids. Paleobios 21, 29 pp.

Boucout, A.J. 1990: Evolutionary paleobiology of behavior and coevolution. 725 pp. Elsevier, Amsterdam.

Bowsher, A.L. 1955: Origin and adaptation of platyceratid gastropods. University of Kansas, Paleontological Contributions, Mollusca 5, 1-11.

Bowsher, A.L. 1956: The effect of the crinoid host on the variability of Permian Platyceratids. In Yochelson, E.L.: Permian Gastropoda of the southwestern United States, Part 1. Bulletin of the American Museum of Natural History 110, 261-263.

Brett, C.E. 1999: Middle Devonian Arkona Shale of Ontario, Canada, and Silica Shale of Ohio, USA. In Hess, H., Ausich, W.I., Brett, C.E. \& Simms, M.J. (eds): Fossil Crinoids, 129-134. Cambridge University Press, Cambridge.
Clarke, J.M. 1908: The beginnings of dependent life. Bulletin of the New York State Museum 121, 1-28.

Clarke, J.M. 1921: Organic Dependence and Disease: Their Origin and Significance. 113 pp. Yale University Press, New Haven, CT.

Ehlers, G.M. \& Kesling, R.V. 1970: Devonian strata of Alpena and Presque Isle counties, Michigan. Miscellaneous Contributions 60, $1-130$.

Gahn, F.J. \& Baumiller, T.K. 2001: Testing evolutionary escalation between crinoids and platyceratid gastropods and phylogenetic analysis of the Compsocrinina (Crinoidea: Monobathrida). Geological Society of America Abstracts with Programs 33, 247.

Hall, J. 1862: Preliminary notice of some of the species of Crinoidea known in the upper Helderberg and Hamilton Groups of New York. New York State Cabinet of Natural History 15th Annual Report, 87-125.

Hall, J. 1879: Descriptions of Gasteropoda, Pteropoda and Cephalopoda of the Upper Helderberg, Hamilton, Portage and Chemung Groups. New York Geological Survey, Paleontology, v.5, part 2, 492 pp.

Hinde, G.J. 1885: Description of a new species of crinoids with articulated spines. Annals and Magazine of Natural History 5th series, 15, 157-173.

Holland, N.D., Leonard, A.B. \& Meyer, D.L. 1991: Digestive mechanics and gluttonous feeding in the feather star Oligometra serripinna (Echinodermata: Crinoidea). Marine Biology 111, 113-119.

Kesling, R.V. \& Smith, R.N. 1962: Gennaeocrinus variabilis, a new species of crinoid from the Middle Devonian Bell Shale of Michigan. Contributions from the Museum of Paleontology, University of Michigan 17, 173-194.

Keyes, C.R. 1888a: On the attachment of Platyceras to Paleocrinoids, and its effects in modifying the form of the shell. Proceedings American Philosophical Society, Transactions 25, 231243.

Keyes, C.R. 1888b: The sedentary habits of Platyceras. American Journal of Science 36, 269-272.

Keyes, C.R. 1890: Synopsis of American Carbonic Calyptraeidae. Proceedings of the Academy of Natural Sciences of Philadelphia for 1890, 150-181.

Kidwell, S.M. \& Jablonski, D. 1983: Taphonomic feedback: ecological consequences of shell accumulation. In Tevesz, M.J.S. \& McCall, P.L. (eds): Biotic Interactions in Recent and Fossil Benthic Communities, 195-248. Plenum, New York.

Kluessendorf, J. 1983: Observations on the commensalism of Silurian platyceratid gastropods and stalked echinoderms. Wisconsin Academy Sciences, Arts and Letters 71, 48-55.

Knight, J.B., Cox, L.R., Keen, A.M., Batten, R.L., Yochelson, E.L. \& Robertson, R. 1960: Systematic descriptions. In Moore, R.C. \& Pitrat, C.W. (eds): Treatise on Invertebrate Paleontology, Part I, Mollusca 1, I169-I324. Geological Society of America and University of Kansas, Lawrence.

Landing, E. \& Brett, C.E. 1987: Trace fossils and regional significance of a Middle Devonian (Givetian) disconformity in southwestern Ontario. Journal of Paleontology 61, 205-230.

Lane, N.G. 1973: Paleontology and paleoecology of the Crawfordsville fossil site (Upper Osagean: Indiana). University of California Publications in Geological Sciences 99, 141 pp.

Lane, N.G. 1984: Predation and survival among inadunate crinoids. Paleobiology 10, 453-458.

Meek, F.B. \& Worthen, A.H. 1866: Radiata, Echinodermata, Crinoidea. Proceedings of the Academy of Natural Sciences of Philadelphia for 1866, 251-275.

Meek, F.B. \& Worthen, A.H. 1868: Notes on some points in the structure and habits of the Paleozoic Crinoidea. Proceedings of the Academy Natural Sciences, Philadelphia, Proceedings for 1868, 323-334.

Meek, F.B. \& Worthen, A.H. 1873: Paleontology, Descriptions of invertebrates from the Carboniferous System. Illinois Geological Survey 5, 323-619, pl. 1-32.

Meyer, D.L. \& Ausich, W.I. 1983: Biotic interactions among Recent and fossil crinoids. In Tevesz, M.F.S. \& McCall, P.L. (eds): Biotic Interactions in Recent and Fossil Benthic Communities, 377-427. Plenum, New York. 
Moore, R.C. \& Laudon, L.R. 1943: Evolution and classification of Paleozoic crinoids. Geological Society of America Special Paper 46, $1-153$.

Owen, R. 1862: Report of a Geological Reconnaissance of Indiana Made During the Years 1859 and 1860. 368 pp. Indianapolis.

Rickard, L.V. 1984: Correlation of the subsurface Lower and Middle Devonian of the Lake Erie region. Geological Society of America Bulletin 95, 814-828.

Rollins, H.B., Brezinski, D.K. 1988: Reinterpretation of crinoidplatyceratid interaction. Lethaia 21, 207-217.

Stumm, E.C. 1951: Check list of fossil invertebrates described from the Middle Devonian Traverse Group of Michigan. Contributions from the Museum of Paleontology 9, 1-44.

Stumm, E.C. 1961: Addenda to the check list of fossil invertebrates described from the traverse group of Michigan. Contributions from the Museum of Paleontology 17, 149-171.

Stumm, E.C. \& Wright, J.D. 1958: Checklist of fossil invertebrates described from Middle Devonian rocks of the Thedford-Arkona Region of Southwestern Ontario. Contributions from the Museum of Paleontology 14, 81-132.

Thomas, A.O. 1924: Echinoderms of the Iowa Devonian. Iowa Geologic Survey, (Annual Reports 1919 and 1920) 29, 385-552.

Ubaghs, G. 1978: Skeletal morphology of fossil crinoids. In Moore, R.C. \& Teichert, C. (eds): Treatise on Invertebrate Paleontology,
Part T, Echinodermata 2(1) T58-T216. Geological Society of America and University of Kansas, Lawrence.

Vermeij, G. J. 1987: Evolution and Escalation. 527 pp. Princeton University Press, Princeton, New Jersey.

Vermeij, G.J. 1994: The evolutionary interaction among species: selection, escalation, and coevolution. Annual Review of Ecologic Systems 25, 219-236.

Vermeij, G.J. 1999: Inequality and the directionality of history. American Naturalist 153, 243-253.

Wachsmuth, C. \& Springer, F. 1881: Revision of the Paleocrinoidea, pt 2. Family Sphaeroidocrinidae, with the sub-families Platycrinidae, Rhodocrinidae, and Actinocrinidae. Proceedings of the Academy of Natural Sciences of Philadelphia for 1881, 175411.

Webster, G.D. 1999: Bibliography and index of Paleozoic crinoids 1986-1990. Geological Society of America Microform Publication 25, $204 \mathrm{pp}$

Webster, G.D. \& Jell, P.A. 1999: New Permian crinoids from Australia. Memoirs of the Queensland Museum 43, 279-339.

Wood, G.D. 1980: Coprolite, urolite, and 'vomite'. Maledicta 4, $109-115$.

Yandell, L.P. 1855: Description of a new genus of Crinoidea. American Journal of Science 20, 135-137.

Yandell, L.P. \& Shumard, B.F. 1847: Contributions to the Geology of Kentucky, 36 pp. Prentice and Weissinger, Louisville, Kentucky. 